\title{
UPAYA-UPAYA PENGELOLAAN SUMBER DAYA IKAN YANG BERKELANJUTAN DI INDONESIA
}

\author{
Suherman Banon') Atmaja dan Duto Nugroho²) \\ 1) Peneliti pada Balai Riset Perikanan Laut, Muara Baru-Jakarta \\ 2)Peneliti pada Pusat Penelitian Pengelolaan Perikanan dan Konservasi Sumberdaya Ikan, Ancol-Jakarta \\ Teregistrasi I tanggal:19 Januari 2011; Diterima setelah perbaikan tanggal: 16 Maret 2011; \\ Disetujui terbit tanggal: 28 Juli 2011
}

\begin{abstract}
ABSTRAK
Pengertian dasar untuk pengelolaan perikanan terkait dengan fungsi fungsi biologi, sosial, teknologi, ekonomi serta lingkungan sumber daya sebagai komponen yang saling berhubungan untuk terjaminnya pengelolaan secara berkelanjutan. Stok ikan, ekosistem dan masyarakat nelayan merupakan salah satu kesatuan yang tidak dapat dipisahkan dalam sistem yang dinamis, dimana perubahan taktik dan strategi pemanfaatan masih merupakan suatu hal yang banyak dilakukan dalam rangka penyesuaian antara faktor teknis dan ekonomis yang sering kali mengabaikan pertimbangan bio-ekologi sumberdaya ikan. Sasaran pendekatan dan kebijakan pengelolaan perikanan di berbagai negara sudah mulai berubah, diawali dengan pendekatan memaksimalkan tangkapan tahunan dan ketenaga-kerjaan menuju ke konservasi dan pengelolaan berbasis pelayanan ekosistem. Konsep pengelolaan berbasis masyarakat dan ko-manajemen masih terbatas pada pengelolaan kawasan konservasi dan habitat terumbu karang. Adanya kesenjangan dan perbedaan antara kepentingan kawasan konservasi sebagai akibat kurangnya pemahaman kolektif terhadap tujuan pengelolaan, dan kerapkali menyebabkan aktifitas perikanan tangkap sebagai bagian dari kebutuhan ekonomis berbenturan dengan fungsi kawasan konservasi dalam jangka panjang. Pengendalian upaya penangkapan dan memahami dinamika perikanan, serta mengelola nelayan menjadi prioritas untuk pengelolaan sumber daya ikan, sedangkan konsep pengelolaan berbasis masyarakat dan ko-manajemen ditempatkan sebagai pelengkap untuk menutupi kelemahan aspek legal wilayah pengelolaan perikanan atau sumber daya ikan.
\end{abstract}

\section{KATAKUNCI: pengelolaan, sumberdaya ikan, ko manajemen}

\section{ABSTRACT: Management Efforts on Sustainable Marine Fish Resources in Indonesia. By Suherman Banon Atmaja and Duto Nugroho.}

Basic understanding of fisheries management related to biology, social, technology and economic function of fish resources. Fish stocks, ecosystem and fishers community are the integrated component under the dynamic of fisheries system, where as changing and on fishing tactic and strategy still exist to adjust between biology, technics and economics aspects. It is obvious that all technological creeps oftenly ignored the bio-ecological consideration of fish resources. The fisheries management and its policy were gradually shifting from maximize the catch, job opportunity become conservation and ecosystem based fisheries management. The concept of community-based management and co management is still limited to the management of conservation areas and coral reef habitats. The existence of gaps and differences between the interests of the conservation area as a result of a lack of understanding collective to the management objectives and often causing fishing activities as part of the economic needs clash with the function

Kosrespondensi penulis:

Jl. Muara Baru Ujung, Komp. Pelabuhan Perikanan Samudera Indonesia

Jakarta Utara-1440. Tlp. (021) 6602044 
of conservation areas in the long term. Control efforts to capture and understand the dynamics of fisheries, as well as managing fishing is a priority for the management of fish resources, while the concept of community-based management and co management issued as a supplement to cover the weakness of legal aspects of the fishery management area or fishery resource

Keywords: Management, fish resources, co-management

\section{PENDAHULUAN}

Perkembangan perikanan yang cenderung semakin mengarah kepada pemanfaatan dengan tidak mengenal kesepakatan batas-batas wilayah pengelolaan maupun penggunaan teknologi yang tidak sejalan dengan konsep ramah lingkungan menyebabkan pengelolaan perikanan tangkap saat ini bukan lagi pada mencari pilihan, tetapi cenderung berada pada kondisi tidak ada pilihan. Dengan adanya tingkat ketidakpastian yang tinggi dihadapi tentang status stok sebagai dasar dalam pengelolalan perikanan dan sering tidak efektifnya implementasi tentang pemikiran ataupun rekomendasi untuk mengurangi kapasitas penangkapan pada tingkat panenan lestari telah menyebabkan beberapa stok ikan berada pada kondisi yang tidak dapat pulih kembali. Seperti halnya beberapa laporan terbaru menyatakan bahwa pengelolaan perikanan selama ini cenderung berkarakteristik kegagalan dibanding keberhasilan, karena lemahnya sistem pengendalian dan pengawasan dan tingginya penguasaan terhadap akses sumber daya ikan telah menimbulkan operasi nelayan di bawah tekanan yang cenderung suka menentang terhadap adanya indikator-indikator penurunan stok dan mendorong ke arah pemanfaatan berlebih baik ekonomi maupun biologi, hingga mencapai tahapan yang dapat dikategorikan sangat mengancam keberadaan dari beberapa spesies. (Berkes, et al.,2001 dan Cunningham, 2005).
Perkembangan upaya penangkapan baik dalam jumlah, ukuran maupun teknologi penangkapannnya telah meningkatkan jumlah ikan yang didaratkan tetapi diikuti oleh runtuhnya stok kelompok jenis ikan pelagis kecil. Fenomena ini diikuti oleh perilaku pembiaran yang semakin kerap didengar terhadap rendahnya tanggung jawab pelaporan hasil tangkapan, pengabaian saran dan pemikiran saintifik serta menyalahkan ancaman lingkungan sebagai faktor utama yang mengakibatkan runtuhnya perikanan yang melanda kawasan sub tropis. Pemanfaatan di daerah penangkapan dekat pantai juga mengalami perubahan tiga dimensi yaitu mengarah pada perairan yang lebih dalam, jenis ikan yang baru serta meningkatnya pemasaran jenis ikan dan invertebrata lain yang sebelumnya ditolak dan umumnya jenis pada tingkatan rantai makanan yang lebih rendah (Pauly, 2009).

Tantangan untuk memelihara sumber daya ikan yang sehat menjadi isu yang cukup kompleks dalam pembangunan perikanan. Konsep pembangunan berkelanjutan adalah pembangunan untuk memenuhi kebutuhan hidup saat ini tanpa merusak atau menurunkan kemampuan generasi mendatang untuk mernenuhi kebutuhan hidupnya (WCED, Commission on Environment and Development, 1987). Dalam pandangan Norton (2005) dalam Howarth (2007) menyatakan bahwa konsep keberlanjutan mengingatkan para pengambil keputusan untuk mempertimbangkan hak dan kepentingan generasi masa depan dan kadang-kadang terdapat kesulitan untuk 
memegang nilai-nilai terhadap lingkungan alam. Konsep tersebut dapat diberikan cukup tepat dalam banyak konteks melalui musyawarah moral yang berusaha untuk menyeimbangkan nilai-nilai dan perspektif dari para pemangku kepentingan yang berbeda.

Dalam konsep pengelolaan sumber daya ikan berkelanjutan terdapat tiga komponen penting yang berjalan dalam kondisi berimbang, yaitu: ekologi, sosial, dan ekonomi. Secara empiris adalah proses tarik ulur antara ketiga kepentingan tersebut (Satria, 2004). Kusumastanto $\left({ }^{*}\right)$ menyatakan bahwa perikanan yang berkelanjutan bukan semata-mata ditujukan untuk kepentingan kelestarian ikan itu sendiri (as fish) atau keuntungan ekonomi semata (as rents) tapi lebih dari itu adalah untuk keberlanjutan komunitas perikanan (sustainable community) yang ditunjang oleh keberlanjutan institusi (institutional sustainability) yang mencakup kualitas keberlanjutan dari perangkat regulasi, kebijakan dan organisasi untuk mendukung tercapainya keberlanjutan ekologi, ekonomi dan komunitas perikanan. Sementara Pitcher dan Pauly (1998) menyatakan bahwa lebih penting untuk memulihkan ekosistem dibandingkan terjaminnya keberlanjutan per se, dan hal ini harus menjadi tujuan dalam pengelolaan perikanan. Keberlanjutan adalah memperdayakan tujuan terkait dengan pemanenan ikan oleh manusia yang mengarah pada terjadinya penyederhanaan terhadap pentingnya ekosistem, tingginya keuntungan, dan semakin rendahnya "trophic level" jenis ikan yang dapat bertahan dari perusakan maupun penurunan kualitas habitat.

Pada dekade terakhir telah diusulkan bahwa konsep MSY didukung oleh "precautionary principle", dimana hal ini dijadikan pertimbangan yang untuk menghindari kemungkinan kerusakan lebih luas atau berdampak negatif pada suatu perikanan. Pendekatan perikanan bernuansa ramah lingkungan dapat berlanjut dan dapat dicapai jika ukuranukuran pengelolaan utama diarahkan untuk mengelola dengan baik agar stok ikan berada diatas "save biological limit" atau pemulihan sumber daya ikan hingga tingkat yang dibutuhkan, diikuti dengan pengurangan secara nyata terhadap hasil tangkap sampingan dan jenis ikan yang tidak termanfaatkan, serta melindungi ekosistem bahari dari aktifitas penangkapan yang merusak lingkungan (Anon, 2009)

Tujuan utama dari makalah ini adalah untuk meninjau beberapa model pengelolaan perikanan dan sejauh mana berjalan menuju pengelolaan sumber daya perikanan berkelanjutan di Indonesia, yang disusun berdasarkan penelusuran pustaka dan, disajikan dalam bentuk esei.

\section{BAHAN DAN METODA}

Telaah terhadap hasil dan temuan penelitian serta peraturan yang telah ditetapkan terkait dengan pengelolaan merupakan bahan utama dalam tulisan ini. Analisis dilakukan dengan cara memetakan fenomena perikanan yang sedang berlangsung didukung oleh diskusi terbatas dengan beberapa pemangku usaha pada saat melakukan observasi lapang

\section{HASIL DAN BAHASAN}

\section{Teknik - Teknik Pengelolaan Perikanan di Indonesia}

Secara teoritis, terdapat dua bentuk regulasi dalam pengelolaan sumber daya perikanan di berbagai belahan dunia, yakni rezim akses terbuka (open access) dan akses terkendali (controlled access). Akses terbuka adalah suatu bentuk regulasi yang 
cenderung membiarkan nelayan menangkap ikan dan mengeksploitasi sumber daya hayati lainnya kapan saja, dimana saja, berapapun jumlahnya, dan dengan alat apa saja. Secara empiris, implikasi dalam jangka panjang terhadap regulasi ini akan menimbulkan dampak negatif, antara lain apa yang dikenal sebagai tragedy of common baik berupa kerusakan sumber daya perikanan maupun konflik antar nelayan. Sebaliknya, pengelolaan dengan system akses terkendali adalah regulasi terkendali yang dijabarkan berupa (1) pembatasan input (input restriction), yakni membatasi jumlah pelaku, jumlah jenis kapal, dan jenis alat tangkap, (2) pembatasan output (output restriction), yakni membatasi berupa jumlah tangkapan bagi setiap pelaku berdasarkan kuota.

Salah satu formulasi dari pembatas input itu adalah territorial use right of fisheries yang menekankan penggunaan fishing right (hak memanfaatkan sumberdaya perikanan) dalam suatu wilayah tertentu dalam yurisdiksi yang jelas. Pola fishing right system ini menempatkan pemegang hak penangkapan ikan melakukan kegiatan perikanan di suatu wilayah, sementara yang tidak memiliki fishing right tidak diizinkan beroperasi di wilayah itu. Selain diatur siapa yang berhak melakukan kegiatan perikanan, juga diatur kapan dan dengan alat apa kegiatan perikanan dilakukan. Sistem yang menjurus pada bentuk pengkaplingan laut utamanya di kawasan pesisir ini menempatkan perlindungan kepentingan nelayan kecil yang beroperasi di wilayah pantai-pesisir serta kepentingan kelestarian fungsi sumber daya (Christy, 1982; Masyhuri, 2004), Namun demikian, dengan mengacu pada "menggunakan hak pemanfaatan dalam pengelolaan perikanan dan pengelolaan berdasarkan hak pemanfaatan" terhadap arti dan konsep diatas dapat menimbulkan kekeliruan dan menimbulkan permasalahan sebagai akibat dari perbedaan pemahaman tentang arti pemanfaatan tersebut dimana realita yang dihadapi adalah timbulnya berbagai jenis dan tipe dari sistem hak kepemilikan dan terdapatnya berbagai cara yang digunakan untuk mengelola perikanan (Anon, 2005)

Beberapa teknik - teknik pengelolaan perikanan sebagai dasar pelestarian sumber daya ikan di Indonesia telah termaktub dalam undang-undang dan berbagai peraturan yang telah ditetapkan. Teknik pengelolaan perikanan menurut Undang-Undang Perikanan (pasal 7 UU 31 Tahun /2004 dan UU 45 tahun 2009 tentang perubahan atas UU 31 tahun 2004 tentang perikanan), yaitu: Pengendalian input meliputi pengendalian jenis, jumlah, ukuran alat penangkapan ikan; jenis, jumlah, ukuran, dan penempatan alat bantu penangkapan ikan; daerah, jalur, dan waktu atau musim penangkapan ikan; persyaratan atau standar prosedur operasional penangkapan ikan; sistem pemantauan kapal perikanan. Pengendalian output meliputi pengendalian ukuran atau berat minimum jenis ikan yang boleh ditangkap. Sebelumnya, upaya pemerintah dalam mengelola perikanan telah ditunjukkan dari berbagai teknik pengelolaan untuk pengaturan, yang meliputi zonasi daerah penangkapan (SK No 607/KPTS/UM/9/ 1976), ukuran mata jaring pada bagian kantong pukat cincin sebesar 1 inci (\# 2,54 cm) (SK No. 123/Kpts/Um/3/1975 dan jalur penangkapan kapal pukat cincin (Kepmentan No. 392/1999), sampai pelarangan secara menyeluruh alat tangkap pukat harimau (Keppres no 39/ 1980) serta pengendalian melalui pungutan hasil perikanan (PHP) menurut PP No 54/ 2002 dan pungutan perikanan (UU 31/2004), Pasal 48 angka 1 dan Pasal 49.

Kepmentan 392 tahun 1999 tentang jalurjalur penangkapan ikan yang berlaku pada 
semua perairan laut Indonesia, yaitu: jalur penangkapan I bagi nelayan kecil (radius 6 mil dari pulau), jalur penangkapan II (6-12 mil) dan jalur penangkapan III (>12 mil). Kapal, alat tangkap dan alat tangkap bantu yang diizinkan untuk jalur I dapat memasuki jalur II dan jalur III, sebaliknya kapal/alat tangkap yang diperuntukan pada jalur yang lebih tinggi tidak diperbolehkan memasuki jalur yang lebih rendah. Tinjauan sosial ekonomi batasan jalur I dari peraturan ini di perairan dangkal adalah pengaturan pemanfaatan diberikan pada nelayan kecil yang beroperasi dalam skala harian dengan modalitas relatif terbatas agar dapat menopang kehidupan kesehariannya. Makna biologis adalah rendahnya kapasitas penangkapan nelayan kecil diharapkan tidak merusak kawasan asuh ikan karena lokasi penangkapan berada disekitar kawasan mereka sendiri, konsep pengelolaan berbasis kearifan lokal diharapkan dapat melindungi keberlanjutan sumber daya ikan dan lingkungannya. Sebaliknya armada yang berukuran lebih besar diarahkan ke jalur II dan III karena tingginya daya tangkap dan modalitas investasi, sehingga mempermudah pergerakan armada yang cenderung berada diluar kawasan kesehariannya, sehingga pemanfaatan sumber daya lebih mengarah pada jenis-jenis yang tidak berada di kawasan asuhan, kecuali kawasan terumbu karang lepas pantai.

Dalam UU Nomor 27 Tahun 2007 tentang Pengelolaan Wilayah Pesisir dan Pulaupulau Kecil, Pasal 1 angka 7 dinyatakan bahwa 12 mil masih dalam zona wilayah pesisir. Konsekuensinya bahwa wilayah pengelolaan $1 / 3$ bagian dari 12 mil laut teritorial yang menjadi wewenang kabupaten/kota adalah wilayah pesisir. Ketentuan tersebut ditegaskan dalam Pasal 18 angka 1 UU No. 32 Tahun 2004 tentang Pemerintahan Daerah. Pada pasal 18 angka 4 secara substansi kabupaten/kota memiliki wewenang mengelola wilayah pesisir masingmasing. Kedua UU tersebut membuat pengaturan tentang yurisdiksi laut provinsi (12 mil) dan kabupaten/kota (4 mil) mengindikasikan bahwa produk hukum itu menganut konsep pengelolaan wilayah laut tertentu berbasis batas-batas yurisdiksi. Konsep tersebut merupakan instrumen yang dapat berfungsi sebagai implementasi dari konsep regulasi akses terkendali sebagai bagian dari pola pembatasan input yang berorientasi pada hak penggunaan berlandaskan wilayah kekuasaan (territorial use right).

Pengelolaan kawasan konservasi laut ke dalam rezim pengelolaan di bawah Departemen Kehutanan, melalui UU. No.5 Tahun 1990 tentang Konservasi Sumber daya alam Hayati dan Ekosistemnya yang merupakan ratifikasi Pemerintah Indonesia terhadap Strategi Pelestarian Dunia (World Conservation Strategy) yang ditetapkan pada tahun 1980. Sementara UU No. 31 Tahun 2004 yang disempurnakan menjadi UU 45/2009 tentang Perikanan (di bawah Departemen Kelautan dan Perikanan), ditetapkan untuk mewujudkan perikanan yang bertanggung jawab dan kelestarian sumber daya ikan, yakni "tercapainya manfaat yang optimal dan berkelanjutan, serta terjaminnya kelestarian sumber daya ikan, pelarangan penangkapan ikan dengan menggunakan bahan dan alat tangkap yang merusak lingkungan dan kelestarian sumber daya”. Implementasi UU 31/2004 ini diturunkan dalam bentuk Peraturan Pemerintah (PP) No. 60 Tahun 2007 tentang Konservasi Sumber daya Ikan yang mengatur lebih rinci upaya pengelolaan konservasi ekosistem atau habitat ikan termasuk di dalamnya melalui pengembangan kawasan konservasi perairan sebagai bagian dari konservasi ekosistem. Peraturan Menteri KP No. 17 tahun 2008 tentang kawasan konservasi di 
wilayah pesisir dan pulau - pulau kecil, juga turut mewarnai perkembangan kebijakan kawasan konservasi di wilayah pesisir dan pulau-pulau kecil. Dalam peraturan ini, Menteri Kelautan dan Perikanan berwenang menetapkan suatu kawasan konservasi perairan, dimana pengelolaannya diberikan kepada pemerintah daerah, khususnya untuk pengembangan KKLD (Kawasan Konservasi Laut Daerah).

Kawasan perlindungan laut (Marine Protected Areas, MPA) muncul sebagai suatu instrumen yang populer untuk konservasi laut dan pengelolaan perikanan. Mengacu pada Resolusi 17.38 IUCN-World Conservation Union (1988) yang ditegaskan lagi dalam Resolusi 19.46 (1994), definisi MPA adalah perairan pasang surut termasuk kawasan pesisir dan pulau-pulau kecil, termasuk tumbuhan dan hewan di dalamnya, serta termasuk bukti peninggalan sejarah dan sosial budaya di bawahnya, yang dilindungi secara hukum atau cara lain yang efektif, baik dengan melindungi seluruh atau sebagian wilayah tersebut (Tilmant, 2000). Secara umum diakui kawasan konservasi bersifat efektif dalam meningkatkan kekayaan spesies standding fish stocks (ikan demersal dan karang), tetapi bagi spesies ikan pelagis yang bersifat peruaya (migratory species) tidak cukup mendapatkan perlindungan dari kawasan konservasi, terutama ukurannya, jumlah dan lokasi jauh lebih sempit dari pada wilayah perikanan.

Pengelolaan sumber daya perikanan dalam banyak hal tidak dapat hanya dilakukan dari pendekatan lokal saja, bagaimanapun sumber daya ikan di kawasan oseanik terdiri dari berbagai kriteria seperti halnya jenis peruaya jauh dan jenis ikan yang berada pada kawasan yang melewati batas-batas ZEE suatu Negara dan laut lepas dalam siklus hidupnya atau dikenal sebagai highly migratory straddling (Maguire et al., 2006).

Perikanan tangkap di Indonesia dapat dibedakan berdasarkan kemampuan jangkauan daerah penangkapan, dengan mengacu pada klasifikasi Yamamoto (1983), yaitu: (i) perikanan pesisir atau coastal fishery, (ii) perikanan lepas pantai atau offshore fishery dan (iii) perikanan laut lepas atau distant-water fishery. Meskipun pada kenyataannnya untuk alat tangkap tertentu kerapkali daerah penangkapan antara perikanan pesisir dengan perikanan lepas pantai tidak dapat dipisahkan secara tegas dan tumpang tindih daerah penangkapan akan terjadi. Apalagi setelah keberhasilan motorisasi dan prasarana dan sarana transportasi semakin baik, sehingga memungkinkan nelayan berpindah-pindah ke tempat lain atau dikenal dengan "andon" sebagai upaya perluasan daerah penangkapan dan menghindari kompetisi di tempat asal. Berdasarkan Keputusan Menteri KP 13 tahun 2004 tentang Pedoman Pengendalian Nelayan Andon Dalam Rangka Pengelolaan Sumberdaya Ikan, nelayan andon adalah nelayan yang melakukan kegiatan penangkapan ikan di laut dengan menggunakan kapal perikanan berukuran tidak lebih dari 30 (tiga puluh) Gross Tonnage (GT) atau yang mesinnya berkekuatan tidak lebih dari 90 (sembilan puluh) Daya Kuda (DK) dengan daerah penangkapan yang berubah-ubah atau berpindah-pindah sehingga nelayan tersebut berpangkalan atau berbasis sementara waktu atau dalam waktu yang relatif lama di pelabuhan perikanan di luar daerah asal nelayan tersebut (pasal 1 angka 2). Setiap nelayan andon yang akan melakukan kegiatan penangkapan ikan di wilayah pengelolaan perikanan Indonesia, wajib terlebih dahulu memiliki Izin Usaha Perikanan (IUP) dan Surat Penangkapan Ikan (SPI) (pasal 3), dikecualikan bagi nelayan andon yang memiliki dan 
menggunakan 1 (satu) unit kapal penangkap ikan berukuran sampai dengan 5 (lima) Gross Tonnage (GT) dan atau yang mesinnya berkekuatan tidak lebih dari 15 (lima belas) Daya Kuda (DK) (pasal 4 angka 1), artinya kewenangan yang dimiliki oleh pemerintah provinsi dan kabupaten/ kota ini tidak berlaku bagi penangkapan ikan oleh nelayan kecil dan tidak akan membatasi usaha nelayan kecil dalam mencari penghidupan. Dengan demikian, nelayan kecil dapat memasuki dan menangkap ikan di wilayah laut daerah tertentu di Indonesia.

Dengan beragamnya bentuk perikanan, tentunya bentuk kebijakan juga beragam tergantung pada hirarki perikanannya. Satria (2004) menerangkan secara simplifikasi ketiga hirarki perikanan tersebut sebagai berikut: (i) Perikanan pesisir yang umumnya digerakkan para nelayan tradisional, kebijakan umumnya dipegang oleh institusi lokal, baik berupa kelompok nelayan, komunitas adat, atau desa, atau populer dengan sebutan community based management (CBM). (ii) Perikanan lepas pantai umumnya mempunyai karakteristik dimensi ekonomi menjadi dominan, karena pelaku perikanan terus mengusung konsep efisensi dan produktivitas, sehingga masalah ekologi kerapkali diabaikan. Kebijakan menggunakan mekanisme perizinan berdasarkan alokasi sumber daya ikan dan kondisi stok ikan atau berupa government based-management. Pemerintah bertugas memonitor dan mengawasi berlangsungnya kebijakan ini. (iii) perikanan laut lepas yang umumnya beroperasi di dalam zona ekonomi eksklusif Indonesia (ZEEI) sampai di luar ZEEI, digerakkan oleh pelaku yang sudah berciri industrial. Mereka padat modal dan berteknologi tinggi. Pada saat ini, kebijakan dikendalikan oleh komisi Internasional yang beranggotakan negaranegara yang berkepentingan terhadap sumber daya di suatu wilayah laut, dan terus berupaya mengembangkan dan kecenderungan menyeimbangkan aspek ekonomi dan ekologi. Seperti, tuna di Pasifik Selatan dipegang CCSBT. Tuna di Laut India dipegang IOTC. Tuna di Atlantik dipegang ICCAT. Kebijakan ini mungkin relatif lebih efektif bagi spesies tuna (Thunnus maccoyii, (Castelnau, 1872) dan beberapa spesies tuna lainnya karena diberlakukan embargo perdagangan Internasional bagi pelanggar.

\section{Pengelolaan Berbasis Masyarakat}

Suatu upaya yang sudah dicoba di wilayah pesisir di Indonesia dan negaranegara lain di Asia yang diharapkan mampu mengatasi kerusakan dan berkurangnya sumber daya adalah merubah pola pikir tentang pemanfaatan sumberdaya ikan dari akses terbuka menjadi kepemilikan umum dengan melibatkan masyarakat, pola ini dikenal dalam bentuk Community-based Coastal Resources Management (CB-CRM) atau pengelolaan sumber daya pesisir berbasis masyarakat (Community-based Management, CBM) adalah proses dimana masyarakat melalui proses politik lokal menyepakati atau menyetujui untuk mengelola sumber daya pesisir atau mengalokasikan sebagian sumber daya yang ada di masyarakat untuk dijadikan kawasan yang dilindungi. Salah satu aktivitas utama di dalam strategi pengembangan komunitas adalah pengembangan kapasitas, di mana warga lokal didorong menjadi lebih aktif dilibatkan dalam manajemen sumber daya lokal (UNEP, 2006). Pengelolaan berbasis masyarakat merupakan salah satu pendekatan dalam upaya mengelola sumber daya di wilayah pesisir, yang cukup menjanjikan dalam rangka meningkatkan partisipasi aktif dari masyarakat dan dalam mendukung pembangunan yang berkelanjutan dan ramah lingkungan. 
Dalam prakteknya yang serupa merupakan hak ulayat yang secara tradisi terbentuk dari suatu kesepakatan bersama pada suatu desa tertentu, yang memiliki hak khusus untuk penangkapan ikan di suatu perairan tertentu dan pada waktu-waktu tertentu pula. Namun demikian, CBM mempunyai keterbatasan., salah satu contoh dari keterbatasan tersebut adalah adanya perubahan-perubahan pola managemen sehubungan dengan meningkatnya jumlah penduduk yang berakibat pada meningkatnya tekanan pada sumber daya yang tersedia, Dengan kata lain CBM akan mengalami perubahan sejalan dengan makin tingginya tuntutan ekonomi masyarakat (Masyhuri, 2004). Sementara Mallawa (2006) menunjukkan kelemahan pada Pengelolaan Sumber daya Perikanan Berbasis Masyarakat (CBM), yaitu: 1) hanya dapat diterapkan dengan baik pada masyarakat yang kondisi strukturnya masih sederhana dengan skala dan wilayah kegiatan yang tidak luas; 2) Tingkat pendidikan dan kesadaran masyarakat tentang pentingnya lingkungan; 3) Terjadinya kesukaran dalam implementasi karena kurang mendapat dukungan; 4) Hanya efektif pada kawasan pengelolaan yang batas geografisnya jelas dan terbatas; dan 5) Rentan terhadap intervensi luar atau peledakan permintaan SDI dan jasa lingkungan. Kemudian muncul konsep ko-manajemen yang telah dikenali secara luas sebagai suatu opsi, yang memberi untuk perubahan institusi penguasaan perikanan. Konsep tersebut pertama kali diperkenalkan oleh Jentoft pada 1989, Pinkerton pada 1989 dan konsep dasar untuk pengelolaan sumber daya alam diperkenalkan oleh Kearney pada 1984, sedangkan kerangka untuk mengerti sumber daya miliki bersama (common property) termasuk aturan pengelolaan dikembangkan oleh Oakerson pada 1992. Pada dekade terakhir konsep komanajemen memasuki debat pengelolaan perikanan dan penerimaan co-management sebagai satu koreksi yang penting pada pengelolaan perikanan yang moderen (Nielsen \& Degnbol, 2002). Ko-manajemen dapat didefinisikan sebagai suatu pengaturan kemitraan dimana masyarakat para pengguna sumberdaya lokal (nelayan), pemerintah, pengguna (stakeholder) lain (pemilik perahu, pedagang ikan, pembuat perahu, bisnis, dll.) dan agen eksternal (organisasi non pemerintahan (NGO), akademis dan lembaga; institusi riset) berbagi tanggung jawab dan otoritas untuk pengelola perikanan. ko-manajemen sering juga disebut partisipatisi, kerjasama, stakeholder multi-party atau manajemen kolaboratif (Charbonneau, 2005). Sedangkan pengelolaan kolaboratif menurut IUCN-World Conservation Union dalam Resolusinya 1.42 Tahun 1996 adalah kemitraan antara lembaga pemerintah, komunitas lokal dan pengguna sumber daya, lembaga non-pemerintah dan kelompok kepentingan lainnya dalam bernegosiasi dan menentukan kerangka kerja yang tepat tentang kewenangan dan tanggungjawab untuk mengelola daerah spesifik atau sumber daya (IUCN, 1997)

Di beberapa wilayah pesisir Indonesia terdapat kepemilikan bersama (communal property) oleh masyarakat nelayan, yang dicerminkan dengan kegiatan pengelolaan sumber daya ikan berbasiskan kearifan lokal atau hak ulayat laut (HUL), di antaranya yaitu: Panglima Laot (Nangroe Aceh Darussalam), Rumpon (Lampung), Kelong (Riau), Awig-awig (Bali dan Lombok), Rompong (Sulawesi Selatan), Sasi (Maluku) dan beberapa lainnya berada di wilayah Kawasan Timur Indonesia (Solihin, 2010). Kearifan lokal yang dikembangkan oleh masyarakat asli (indigenous people) atau masyarakat adat, dianggap mampu menjembatani antara tuntutan pembangunan dengan tetap menciptakan kondisi lingkungan yang sehat (Siswandi, 
2003 dalam Solihin, 2010). Bagi daerah yang memiliki kearifan lokal atau model pengelolaan CBM, perlu diperkuat dan dilengkapi dengan ko-manajemen yang lebih kompleks (Solihin dan Satria, 2007). Dengan merevitalisasi kearifan lokal di era desentralisasi kelautan dapat menciptakan pembagian wewenang yang seimbang antara pemerintah (centralized government management) dengan masyarakat (community based management), yang dikenal dengan pengelolaan kolaboratif atau ko-manajemen.

Di Indonesia, penerapan konsep komanajemen masih terbatas pada pengelolaan sumber daya ikan dan habitat terumbuk karang, seperti TN Bunaken dan TN Wakatobi, tetapi masih kurang efektif karena appropriate sharing kurang diakomodir dalam penataan kelembagaan (Radarwati, et.al., 2010).

\section{Permasalahan Perilaku}

Keberhasilan pengelolaan perikanan pendekatan ekosistem sangat tergantung pada dua hal, terutama atas: (1) kesediaan nelayan untuk menerima tanggung jawab kolektif untuk konservasi sumber daya dan (2) keberadaan institusi yang menyediakan suasana keputusan kolektif dapat diperdebatkan dan dibuat (Wilson, 2003). UNEP (2007) mengidentifikasi bahwa meningkatkan upaya penangkapan, menggabungkan dengan berlanjutnya kemunduran total kawasan habitat kritis terhadap siklus hidup dari kebanyakan spesies, telah menjadi perhatian serius untuk keberlajutan jangka panjang dari perikanan-perikanan artisanal di Asia Tenggara. Prakarsa untuk mengintegrasikan pengelolaan perikanan dan habitat akan dibatasi oleh penghalang terhadap tindakan yang efektif sebagai berikut: 1) Informasi terbatas mengenai daur hidup ikan dan pertalian-pertalian dengan habitat kritis, dan peran habitat dalam mendukung perikanan; 2) rendahnya tingkat pemahaman yang berkaitan habitat dengan stok ikan, antara stakeholders termasuk nelayan, para ilmuwan, pembuat kebijaksanaan, dan para manajer perikanan; 3) rendahnya tingkat penerimaan masyarakat terhadap pendekatan berbasis kawasan perlindungan laut; dan 4) pengalaman terbatas departemen perikanan dan lingkungan dalam pelayanan berkenaan dengan implementasi perikanan yang terintegrasi dan pendekatan pengelolaan habitat

Perilaku nelayan di kawasan Asia Tenggara, termasuk Indonesia, pada umumnya masih pada tahapan konvensional, yaitu menitikberatkan pada kepentingan diri sendiri dan berorientasi pada kepentingan jangka pendek. Nelayan cenderung melanggar peraturan perikanan karena disebabkan faktor-faktor: ekonomi, moralitas, lingkungan, dan legitimasi. Sesuai dengan teori pilihan yang rasional, individu nelayan akan memilih melanggar aturan apabila mereka dapat memperkirakan bahwa manfaat yang akan mereka peroleh masih lebih menguntungkan dibanding resiko yang harus ditanggung bila tertangkap (Wijayanto, 2003). Morgan, et al. (2007) menyimpulkan bahwa karakteristik perikanan tangkap di Asia Tenggara adalah pengembangan dan pengelolaan pantai yang kompleks. Konflik antar berbagai para pengguna sumber daya akuatik, merosot sumber daya perikanan, kelebihan kapasitas, penangkapan ikan bersifat merusak (destructive fishing), IUU fishing. Ada kompetisi tidak adil antara perikanan skala besar dan nelayan skala kecil. Kelebihan kapasitas \& IUU fishing telah mengakibatkan kerangka pengelolaan yang tidak efektif. Hukum, peraturan-peraturan dan aturan-aturan diperumit dengan penyelenggaraannya yang lemah 
Kesadaran masyarakat terhadap prinsipprinsip konservasi pengelolaan sumber daya perikanan nampaknya sangat sulit dilaksanakan karena adanya kebutuhan ekonomi jangka pendek yang mendesak dan beragamnya pemahaman mereka (nelayan) terhadap kelestarian. Sebagai contoh sebagian nelayan Karimunjawa tidak peduli dan tidak mau tahu akan keberadaan daerah-daerah perlindungan, di sisi lain, nelayan Karimunjawa menyadari bahwa tidak akan ada sanksi terhadap pelanggaran memasuki kawasan zona inti maupun zona perlindungan, karena pengawasan sulit dilaksanakan dan kalau pun ada pengawasan tidak akan terjadi apa-apa pada mereka (Mukminin, et al., 2006). Pada pelaksanaannya kawasan konservasi kerapkali kurang efektif, karena adanya kesenjangan dan disharmonisasi aturan pengelolaan dan pemanfaatan di kawasan konservasi, serta perbedaan kepentingan dengan masyarakat karena kurangnya pemahaman masyarakat tujuan pengelolaan, sehingga banyak pelanggaran hukum di bidang pengelolaan sumber daya alam tidak mendapat sanksi hukum, selain itu tingkat pendidikan yang masih rendah dan juga didorong oleh kebutuhan hidup (Purwanti, et al., 2008). Sementara data empiris menujukkan pada kawasan padat nelayan seperti Laut Jawa lebih banyak ditemukan modifikasi dan diversifikasi alat tangkap untuk menangkap segala spesies yang masih tersedia. Dengan modifikasi dan divertifikasi di daerah penangkapan padat nelayan dan lebih tangkap tanpa pengelolaan yang tepat akan menggangu pengelolaan sumber daya perikanan yang berkelanjutan.

Harapan pengelolaan sumber daya perikanan berkenjutan masih berhadapan dengan permasalahan dasar "human dimension", sehingga pengelolaan sumber daya perikanan yang ada saat ini belum berjalan optimal dan berkelanjutan. Situasi ini didukung dari beberapa penelitian yang menyimpulkan secara umum, seperti : pemberdayaan SDM, pengurangan armada kecil yang tidak efisien dan tidak ramah lingkungan, kapasitas kelembagaan perikanan dan kelautan, pemanfaatan sumber daya ikan harus sesuai dengan potensi lestari, rehabilitasi habitat lamun dan mangrove, pelarangan penangkapan pada waktu-waktu tertentu, melakukan budidaya, peningkatan pengawasan dan penegakan hukum di wilayah pesisir dan laut (Susilo, 2003, Pramono, 2006,. Hamdan, 2008, Radarwati, et.al., 2010). Dengan demikian, suatu proses menuju pengelolaan perikanan berkelanjutan masih dalam konsep yang bersifat himbauan moral. Oleh karena itu, pengendalian upaya penangkapan dan memahami dinamika perikanan, serta mengelola nelayan menjadi prioritas untuk pengelolaan sumber daya ikan, sedangkan konsep pengelolaan berbasis masyarakat dan co management ditempatkan sebagai pelengkap untuk menutupi kelemahan wilayah pengelolaan perikanan/sumber daya ikan Republik Indonesiayang tertuang dalam UU 31 Tahun /2004 dan UU 45 tahun 2009 tentang perubahan atas UU 31 tahun 2004 tentang perikanan.

\section{KESIMPULAN}

Berdasarkan konsep-konsep pengelolaan dari konvensional sampai berbasis masyarakat dan ko-manajemen menunjukan pengelolaan sumber daya perikanan yang ada saat ini belum berjalan optimal dan berkelanjutan. Pengelolaan bersama maupun pengelolaan sumber daya perikanan berbasis ekosistem berhadapan dengan suatu kondisi masalah klasik seperti tidak adanya alternatif lapangan kerja, tingkat pendidikan rendah, kemiskinan.dan penegakan hukum yang lemah. 
Pengendalian upaya penangkapan dan memahami dinamika perikanan, serta mengelola nelayan menjadi prioritas untuk pengelolaan sumber daya ikan, sedangkan konsep pengelolaan berbasis masyarakat dan ko manajemen dtempatkan sebagai pelengkap untuk menutupi kelemahan wilayah pengelolaan perikanan/sumber daya ikan Republik Indonesiayang tertuang dalam UU 31 Tahun /2004 dan UU 45 tahun 2009 tentang perubahan atas UU 31 tahun 2004 tentang perikanan.

Sebagaimana banyak dipahami bahwa suatu sumber daya yang bersifat common, ketika terjadi penurunan stok maka tidak mudah untuk dibagi-bagikan di dalam pemanfaatannya. Persoalan ekstemalitas tetap akan muncul pada saat sumber daya perikanan dlmanfaatkan, karena ekstemalitas - merupakan suatu dilema yang menjadi ciri khas sendiri dan membedakannya dari sumber daya lainnya. Ekstemalitas muncul ketika nelayan menangkap tidak akan memperhitungkan akibatnya bagi nelayan lain, atau pemanfaatan sumber daya yang dilakukan seorang individu akan berpengaruh pada individu yang lain.

\section{DAFTAR PUSTAKA}

Anonymous,. 2005. World inventory of fisheries. Property rights and fisheries management. Issues Fact Sheets In: FAO Fisheries and Aquaculture Department [online]. Rome. Updated 27 May 2005. (http://www.fao.org/fishery/ topic/13335/en Cited 25 April 2011)

2009. Towards Sustainable Fisheries. Comment to the Commission's Green Paper "Reform of the Common Fisheries Policy"(COM(2009)163 final). October 2009 No. 7. SRU, German Advisory Council on the environment. $14 \mathrm{pp}$.
Berkes, F.; R. Mahon; P. McConney, R. Pollnack, \& R.Pomeroy, 2001. Managing small-scale fisheries, alternative directions and methods. IDRC. www.idrc.ca. 320 pp.

Cunningham, S. 2005. Successful fisheries management, Issues, Case Studies, and Perspectives. Science 22 June 2007: 316. (5832). 1713-1716.

Charbonneau, R., 2005. What is Community-based Co-management in Fshery Co-Management. A Practical Handbook R.S. Pomeroy and R. RiveraGuieb (eds). IDRC(International Development Research Centre):1-18

Christy, F.T.Jr. 1982. Territorial use rights in marinefisheries: definitions and conditions. FAO Fish. Tech.Pap., (227): $10 \mathrm{pp}$.

Fauzi, A. 2005. Kebijakan perikanan dan kelautan, isu, sistesis dan gagasan. Gramedia. 187p

Garcia, S.M.; Newton, C. 1994. Current situation, trends and prospects in world capture fisheries. Paper presented at the Conference on Fisheries Management, Global Trends, June 1994, Seattle, Washington, DC, USA

Graham, J., A. Charles and A. Bull. 1971. Community Fisheries Management Handbook. Gorsebrook Research Institute, Saint Mary's University, 2006. $138 \mathrm{pp}$.

Hamdan. 2008. Analisis Kebijakan Pengelolaan Perikanan Tangkap Berkelanjutan di Kabupaten Indramayu. (disertasi). Program Pascasarjana IPB. Bogor. 199 hal (tidak dipublikasikan) 
Howarth R.B..2007. Sustainability and the Fair-Sharing Principle, Environmental Studies Program Dartmouth College, Hanover, New Hampshire www.epa.gov/ sustainability! pdfs/howarth-epa-ordpaper.pdf (downloaded 26/04/2011).

Kusumastanto. T. $\left(^{*}\right)$. .Revitalisasi Sektor Kelautan dan Perikanan secara Berkelanjutan. tridoyo.blogspot.com

Mallawa A, 2006. Pengeloaan Perikanan Sumberdaya Ikan Berkelanjutan dan Berbasis Masyarakat. Lokakarya Agenda Penelitian Program Coremap II Kabuoten .9-10 September 2006

Maguire, J.J., M.Sissenwine, J. Csirke, R. Grainger and S. Garcia, 2006. The state of world highly migratory, straddling and other high seas fishery resources and associated species. FAO. Rome.

Masyhuri, 2004. Co-Management dan Pengelolaan Sumber daya Perikanan di Era Otonomi. Jur. Ekonomi dan Pembangunan, XII (2):72- 96

Mukminin, A., T. Kartawijaya, Y. Herdiana, I. Yulianto. 2006. Laporan Monitoring. Kajian Pola Pemanfaatan Perikanan di Karimunjawa (2003-2005). Wildlife Conservation Society - Marine Program Indonesia. Bogor, Indonesia. 35pp.

Morgan, G., D. Staples and S.F. Smith. 2007. Fishing capacity management and IUU fishing in Asia. Asia-Pacific Fishery Commmision FAO of The United Nations Regional Office for Asia and the Pacific. Bangkok. RAP publication 2007/16. 28pp.

Mullon, C., P. Fréon and P. Cury, 2005. The dynamics of collapse in world fisheries. Fish and Fisheries. 6: 111-120.
Nielsen J. R. \& P. Degnbol. 2002. Fisheries Co-Management - An Institutional Innovation. Perspectives and Challenges Ahead. Paper no 216. Institute for Fisheries Management and Coastal Community Development (IFM).

Pauly D., V. Christensen, S. Guénette, T.J. Pitcher, U. R. Sumaila, C.J. Walters, R. Watson \& D. Zeller, 2002. Towards sustainability in world fisheries. Nature 418: 689-695. www.nature.com/nature

Pauly, D. 2009. Beyond duplicity and ignorance in global fisheries. Scienta Marina 73 (2). June 2009. p.215-224.

Pitcher, T.J. and D. Pauly. 1998. Rebuilding ecosystems, not sustainability, as the proper goal of fishery management. in Reinventing Fisheries Management ed T. Pitcher, D. Pauly \& P. Hart, (1998) Chapman \& Hall Fish and Fisheries Series. Pages 311-325 (Chapter 24 ).

Pomeroy, R. S., M.B. Mascia \& R. B. Pollnac, 2006. Marine Protected Areas: The Social Dimension. FAO Expert Workshop on Marine Protected Areas and Fisheries Management: Review of Issues and Considerations (12-14 June, 2006)

Pramono, B. 2006. Strategi Pengelolaan Perikanan Jaring Arad yang Berbasis di Kota Tegal. Tesis. Program Pascasarjana. IPB. Bogor. 100 hal (tidak dipublikasikan)

Purwanti, F, H.S Alikodra, S.Basuni \& D. Soedharma. 2008. Pengembangan CoManagement Taman Nasional Karimunjawa. IImu Kelautan. Vol 13(3):159-166

Radarwati, S., M. S,. Baskoro, D. R. Monintja, A. Purbayanto. 2010. Analisis 
Faktor Internal - Eksternal Dan Status Keberlanjutan Pengelolaan Perikanan Tangkap Di Teluk Jakarta. Jurnal Teknologi Perikanan Dan Kelautan. 1 (1).

Satria, A., 2004. Paradigma Perikanan Berkelanjutan. Republika, 16 Juli 2004

Solihin. A. \& A. Satria, 2007. Hak Ulayat Laut di Era Otonomi Daerah sebagai Solusi Pengelolaan Perikanan Berkelanjutan: Kasus Awig-awig di Lombok Barat. Jur. Transdisplin Sosiologi, komunikasi dan Ekologi Manusia. 1 (1) : 67 -86.

Solihin A. 2010. Desentralisasi Kelautan dan Revitalisasi Kearifan Lokal. www.mediaindonesia.com/webtorial/klh/ index.php

Susilo, S. B. 2003. Keberfanjutan Pembangunan Pulau-Pulau Kecil: Studi Kasus Kelurahan Pulau Panggang Dan Pulau Pari, Kepulauan Seribu, DKI Jakarta. Disertasi. Program Pascasarjana IPB. Bogor. 233 hal. (tidak dipublikasikan)
Tilmant, J. 2000. Coral reef protected areas: A guide for management. U.S Coral Reef Task Force. Departement of the Interior. Washington. 14 pp.

Tridoyo Kusumastanto, T (*) Revitalisasi Sektor Kelanjutan dan Perikanan Secara Berkelanjutan. Pusat Kajian Sumberdaya Pesisir dan Lautan. Institut Pertanian Bogor. tridoyo.blogspot.com

UNEP, 2007. Procedure for Establishing a Regional System of Fisheries Refugia in the South China Sea and Gulf of Thailand in the context of the UNEP/GEF project entitled: "Reversing Environmental Degradation Trends in the South China Sea and Gulf of Thailand". South China Sea Knowledge Document No. 4. UNEP/GEF/SCS/Inf.4

Wilson, D.C. 2003. The community development tradition and fisheries comanagement. In: "The Fisheries Comanagement Experience

Wijayanto, D., 2003. Wacana Modernisasi Perikanan Nasional. www.sinarharapan.co.id/ berita/0611/22/ opi01.html 